\title{
Performance of ambient and freezing-thawing cured metazeolite and slag based geopolymer composites against elevated temperatures
}

\author{
Yurdakul Aygörmez (Main and Corresponding Author) \\ Department of Civil Engineering Davutpasa Campus, Yildiz Technical University \\ Esenler, 34220, Istanbul (Turkey) \\ aygormez@yildiz.edu.tr
}

Manuscript Code: 19643

Date of Acceptance/Reception: 07.03.2021/23.08.2020

DOI: 10.7764/RDLC.20.1.145

\begin{abstract}
Today, geopolymer has an important place in producing sustainable alternative products by consuming less energy. This paper researches the elevated-temperature behavior of metazeolite (MZ) and slag (S) based geopolymer composites, reinforced by polyvinyl alcohol fiber (PVA) (at $0.3 \%$, $0.6 \%$ and $0.9 \%$ by volume), and basalt fiber (B) (at $0.3 \%, 0.6 \%$ and $0.9 \%$ by volume). The curing was carried out at room temperature for up to 7 days and then the freeze-thaw test was applied as a curing method for up to 28 days. Slag was used alongside metazeolite to solve the problem of delayed setting time with its high Ca content. After 7 days, the damp environment provided by the freeze-thaw curing ensured the preservation of the compact structure and the continuation of geopolymerization. The resulting geopolymer composites were exposed to temperatures of 250,500 , and $750{ }^{\circ} \mathrm{C}$. The flexural and compressive strengths, microstructure (FT-IR, XRD, SEM, TGA-DTA, and micro-CT analyzes), ultrasonic pulse velocity (UPV), visual inspection, and weight-losses of the geopolymers were examined to evaluate their behavior. According to the results, it was observed that geopolymer samples maintained their stability after $750^{\circ} \mathrm{C}$. In this way, a sustainable geopolymer composite was produced by using less energy.
\end{abstract}

Keywords: geopolymer, metazeolite, slag, polyvinyl alcohol fiber, basalt fiber, freezing-thawing, high-temperature.

Introduction

Geopolymer is a potential alternative binder that requires low energy in its production and provides low greenhouse gas emissions, meeting the sustainability criteria better than portland cement (Duxson et al., 2007). Geopolymers are inorganic polymer materials with a three-dimensional Si-O-Al framework produced by synthesizing aluminosilicates by dissolving in an alkaline environment (Davidovits \& Sawyer, 1985). In addition to numerous natural aluminosilicates, alkali activation of slag, mineral waste, and industrial by-products produce an interesting and sustainable cold-hardening cement (Provis, 2014). Metakaolin is one of the important materials in this sense. Metakaolin is produced by calcining kaolin at $750^{\circ} \mathrm{C}$. Metakaolin has often been utilized as reference material to handily search the consolidation reaction among these aluminosilicate starter materials (Ali et al., 2020; Aygörmez, Canpolat, Al-mashhadani, et al., 2020; Billong et al., 2018; Jaya et al., 2020; Uysal et al., 2018).

The properties of geopolymer materials indicate that it would be appropriate to use them instead of portland cement in the construction sector. Also, releasing high $\mathrm{CO}_{2}$ in the production of portland cement is the other factor that has accelerated the search for alternatives (Rivera et al., 2014; Si et al., 2020). One of the important materials that can be calcined is zeolite. Due to the low pozzolanic feature of zeolite, it creates a significant decrease in compressive strength by substituting more than $10 \%$ instead of cement. This depends on the particle size and pozzolanic reactivity of the zeolite. The low pozzolanic reactivity of the zeolite leads to a slowdown in hydration (Jalilifar et al., 2020). This is also true for geopolymer production. Zeolite can naturally use as a geopolymer precursor (Nikolov et al., 2020; Nikolov \& Rostovsky, 2017). Both cases have been used in studies on zeolite. When zeolite is used as a binder material, geopolymerization remains at a low rate. Lower results were obtained in studies on natural zeolite compared to studies using metazeolite.

Besides, samples with natural zeolite showed a higher shrinkage tendency. The main reason for this situation is that natural zeolite needs a significant amount of water. While values between 5-15 MPa were obtained in geopolymer samples prepared with natural zeolite at room temperature, values between 25-35 MPa were obtained in samples cured between 50-70 ${ }^{\circ} \mathrm{C}$ (Nikolov \& Rostovsky, 2017; Özen \& Alam, 2018). However, when the zeolite is calcined, the pozzolanic reactivity increases and it can reach the potential to be used as a binder in geopolymer production. In the samples using calcined zeolite, values around $43 \mathrm{MPa}$ were obtained when high-temperature curing was applied (Nikolov et al., 2017). Geopolymerization is dependent on the type of curing system. There are many studies on geopolymerization related to high curing temperatures $\left(40-90^{\circ} \mathrm{C}\right.$ ) (Al-mashhadani et al., 2018; Özen \& Alam, 2018; Uysal et al., 2018). Rovnaník, (2010) and Burciaga-Díaz et al. (2016) experimented with different curing times, taking into account different temperatures (between 10 and $80^{\circ} \mathrm{C}$ ) for geopolymer curing. 
The conclusions were evaluated in terms of bending and compressive strengths, pore properties, and microstructure analysis. The results showed that the curing temperature influenced the mechanical properties by changing the pore structure. According to these studies, it was observed that high results were obtained. However, when the heat curing was applied, the long-term effects were reversed. The high curing temperature increased the reaction products by accelerating the dissolution of the binder. However, over time, this situation negatively affected the quality of the reaction products and the homogeneity microstructure. In this case, with the thermolysis of the $-\mathrm{Si}-\mathrm{O}-\mathrm{Al}-\mathrm{O}-\mathrm{bond}$, strength decline occurred at a later time (Aygörmez, Canpolat, \& Al-mashhadani, 2020a, 2020b; Heah et al., 2011). Due to this situation, there has been a search for different curing methods. Room temperature curing is another method. In the case of the application of the room temperature curing condition, lower strength results were obtained (Nikolov \& Rostovsky, 2017; Özen \& Alam, 2018).

Also, the initial setting time was found to last more than 24 hours (Shinde \& Kadam, 2015). Materials with high Ca content are useful to overcome this problem. Slag, produced by melting metal ore, has a high ratio of $40 \% \mathrm{Ca}$ as well as high silica and alumina content. The use of slag is an important alternative to overcome the problem of hightemperature requirements for curing (Dombrowski et al., 2007). It was also determined that geopolymer mortars produced with slag were important for durability properties. In their study by Bingöl et al. (2020), geopolymer mortars produced using sodium metasilicate with three sodium concentrations of $4 \%, 8 \%$, and $12 \%$ by mass were used in aggressive conditions (high-temperature, rapid chloride permeability, abrasion, and wetting-drying cycles). It was shown that high performance was achieved. This situation supported the important contribution of slag.

The geopolymer's binding excellent degree is concerning to the three-dimensional "N-A-S-H" gel and this strong bond is identified as a network of $\mathrm{SiO}_{4}$ and $\mathrm{AlO}_{4}$ tetrahedra by sharing oxygen atoms. When the thermal phases for the structure were examined, it was observed that the geopolymer had a superior fire resistance than OPC (Pan et al., 2017; Sarker \& McBeath, 2015; Zhang et al., 2016). For alkali-activated concrete with a high-temperature effect, partial sintering was seen, and, therefore, an increase in compressive strength was detected (Shaikh \& Vimonsatit, 2015). Davidovits (2008) showed that resistance to fire was obtained at $1200^{\circ} \mathrm{C}$ with the potassium and sodium activators. Barbosa \& MacKenzie (2003) detected similar results using sodium silicate and hydroxide. The samples were found to provide stability until melting at $1000-1300{ }^{\circ} \mathrm{C}$. Valencia Saavedra \& Mejía de Gutiérrez (2017) used OPC for comparison when conducting a high-temperature test for alkali-activated fly ash-based cement. While the strength increase was observed in the alkali-activated samples after $600^{\circ} \mathrm{C}$, OPC samples showed a decrease in strength.

Duan et al. (2017) examined the mechanical properties by exposing thermal cycles to fly ash and silica fume-based geopolymer composites. Heating and cooling cycles (with 7, 28, and 56 cycles) were applied at three different temperatures: 200,400 , and $800^{\circ} \mathrm{C}$. An improvement in the results was seen due to the silica fume effect. At the end of the cycles, it was seen that the increasing temperature adversely affected the strength and weight loss. It is possible to improve the geopolymer samples' mechanical properties using fibers. The reaction process for the matrix structure is strengthened with this effect. Carbon, glass, woven fabrics, and basalt fibers were used in dissimilar studies (Amuthakkannan et al., 2013; Assaedi et al., 2015). Dias \& Thaumaturgo (2005) showed favorable effects on the fracture toughness of basalt fiber-reinforced geopolymer composites. The contribution of the fiber was found to positively reduce deformation. Xu et al. (2017) investigated PVA fiber-reinforced geopolymer composites, and Tanyildizi \& Yonar (2016) examined the high-temperature performance of PVA fiber-reinforced geopolymer concrete. Both studies achieved high performance.

These fiber effects, obtained with high-temperature curing, will be investigated in this study. Zeolite is an important alternative in geopolymer production due to its low cost, natural and widespread nature. However, studies have shown that high-temperature curing is necessary for strength development. So high temperatures that requiring high energy were generally used as curing conditions in geopolymer production. In this study, a method in which room temperature and freeze-thaw action were affected together, instead of high curing temperatures, was tried. Slag was also added to the mixture to ensure setting in room conditions. In this method, geopolymer samples were cured for up to 7 days at room temperature and then for up to 28 days under freezing-thawing. While metazeolite and slag were used as the binders in the produced samples, $0.3 \%, 0.6 \%$, and $0.9 \%$ by volumes of PVA and basalt fibers were used as reinforcers. $\mathrm{A}$ total of 7 series were produced together with a fiber-less control series and subjected to high temperatures of 250, 500, and $750^{\circ} \mathrm{C}$ after 28 days.

The samples were examined with flexural strength, compressive strength, UPV, and weight loss properties. XRD, SEM, TGA-DTA, micro-CT, and FT-IR analyzes and visual inspection were carried out for detailed examinations. 


\section{Raw materials}

Geopolymer samples were fabricated with metazeolite. Metazeolite is produced by calcining zeolite at $750{ }^{\circ} \mathrm{C}$. Zeolite has a grain size of $2-3 \mathrm{~mm}$. Its specific gravity is $2.17 \mathrm{~g} / \mathrm{cm}^{3}$ and Blaine's specific surface value is $9660 \mathrm{~cm}^{2} / \mathrm{g}$. The degree of geopolymerization increases with the metazeolite's fine-grained structure. Slag was also utilized as a binder material. Its specific gravity is $2.91 \mathrm{~g} / \mathrm{cm}^{3}$ and Blaine's specific surface value is $4500 \mathrm{~cm}^{2} / \mathrm{g}$. Table 1 shows the chemical composition of raw materials. Sodium silicate $\left(\mathrm{SiO}_{2} / \mathrm{Na}_{2} \mathrm{O}=3.29\right)$ and sodium hydroxide $(12 \mathrm{M})$ were utilized for the alkali activator mixture. The sodium hydroxide used in the study was supplied in solid form and the solution was prepared with water. Sodium silicate was supplied directly in liquid form. Rilem sand (by following BS EN 196-1) was mixed as an aggregate. Basalt and polyvinyl alcohol fibers were added with different ratios (Table 2).

\begin{tabular}{|c|c|c|c|c|c|c|c|c|c|}
\hline $\begin{array}{c}\text { Chemical } \\
\text { content, \% }\end{array}$ & $\mathrm{SiO}_{2}$ & $\mathrm{Al}_{2} \mathrm{O}_{3}$ & $\mathrm{Fe}_{2} \mathrm{O}_{3}$ & $\mathrm{CaO}$ & \multicolumn{2}{|c|}{$\mathrm{MgO}$} & $\mathrm{K}_{2} \mathrm{O}$ & $\mathrm{Na}_{2} \mathrm{O}$ & L.O.I. \\
\hline $\mathrm{MZ}$ & 76.90 & 13.50 & 1.40 & 2.10 & \multicolumn{2}{|c|}{1.10} & 3.50 & 0.40 & 1.10 \\
\hline \multirow[t]{5}{*}{$S$} & 40.60 & 12.83 & 1.37 & 36.08 & \multicolumn{2}{|c|}{6.87} & 0.68 & 0.79 & 0.78 \\
\hline & \multicolumn{8}{|c|}{ Table 2. The fibers' properties. (Self-Elaboration). } & \\
\hline & Fiber Type & $\begin{array}{c}\text { Length } \\
(\mathrm{mm})\end{array}$ & $\begin{array}{l}\text { Diameter } \\
\quad(\mu \mathrm{m})\end{array}$ & $\begin{array}{l}\text { r Spe } \\
\text { Gra }\end{array}$ & & $\begin{array}{r}\text { No } \\
\text { Te } \\
\text { Str } \\
\text { (I }\end{array}$ & $\begin{array}{l}\text { inal } \\
\text { sile } \\
\text { gth } \\
\text { a) }\end{array}$ & $\begin{array}{c}\text { Aspect } \\
\text { Ratio }\end{array}$ & \\
\hline & PVA & 8 & 39 & & & & & 90 & \\
\hline & Basalt & 12 & 20 & & & & & 800 & \\
\hline
\end{tabular}

\section{Mix design and specimen preparation}

The sodium hydroxide solution (12M) was prepared and left for 2 hours to cool, then mixed with the sodium silicate solution. No extra water was added when preparing the mixture. Water was used when preparing a sodium hydroxide solution. Therefore, instead of the water/binder ratio, sodium hydroxide/binder ratio and sodium silicate/binder ratio have been taken into consideration. The constant 2:1 ratio was taken into account for the sodium silicate/sodium hydroxide solution mixture. The mixture of activator was blended with the binder materials (metazeolite and slag) at a constant ratio of 1.2:1. Metazeolite and slag were used equally in the binder mixture. When metazeolite was used alone, there were problems in the setting. So the use of slag was aimed at shortening the setting time. When metazeolite was used alone, the setting time was around 24 hours. In the case of using slag, the setting time decreased to 2 hours. The mortars became to be removed from the mold after 2 hours.

Finally, rilem sand was added to the mixture at 2.5 times the amount of the binder materials. The prepared mixture was subjected to vibration after being placed in molds. In mortars produced using Portland Cement, $1350 \mathrm{~g}$ of sand is used as a standard for $450 \mathrm{~g}$ of the binder. However, it is not possible to specify such a standard in geopolymer production. Mixing ratios vary according to the type of binder material. Due to this situation, the material quantities were determined with preliminary trial mixes to achieve the most appropriate mortar consistency. The procedure used for the mixture (for $450 \mathrm{~g}$ of binder material) is shown in Figure 1. Room temperature was used for up to 7 days as a curing condition and a freeze-thaw cycle was performed between 7 days and 28 days. 1 cycle consisted of 12 hours at a temperature of $+4^{\circ} \mathrm{C}$ and 12 hours at $-18^{\circ} \mathrm{C}$. A total of 21 cycles were applied. After 28 days, the samples were subjected to high-temperature tests. 


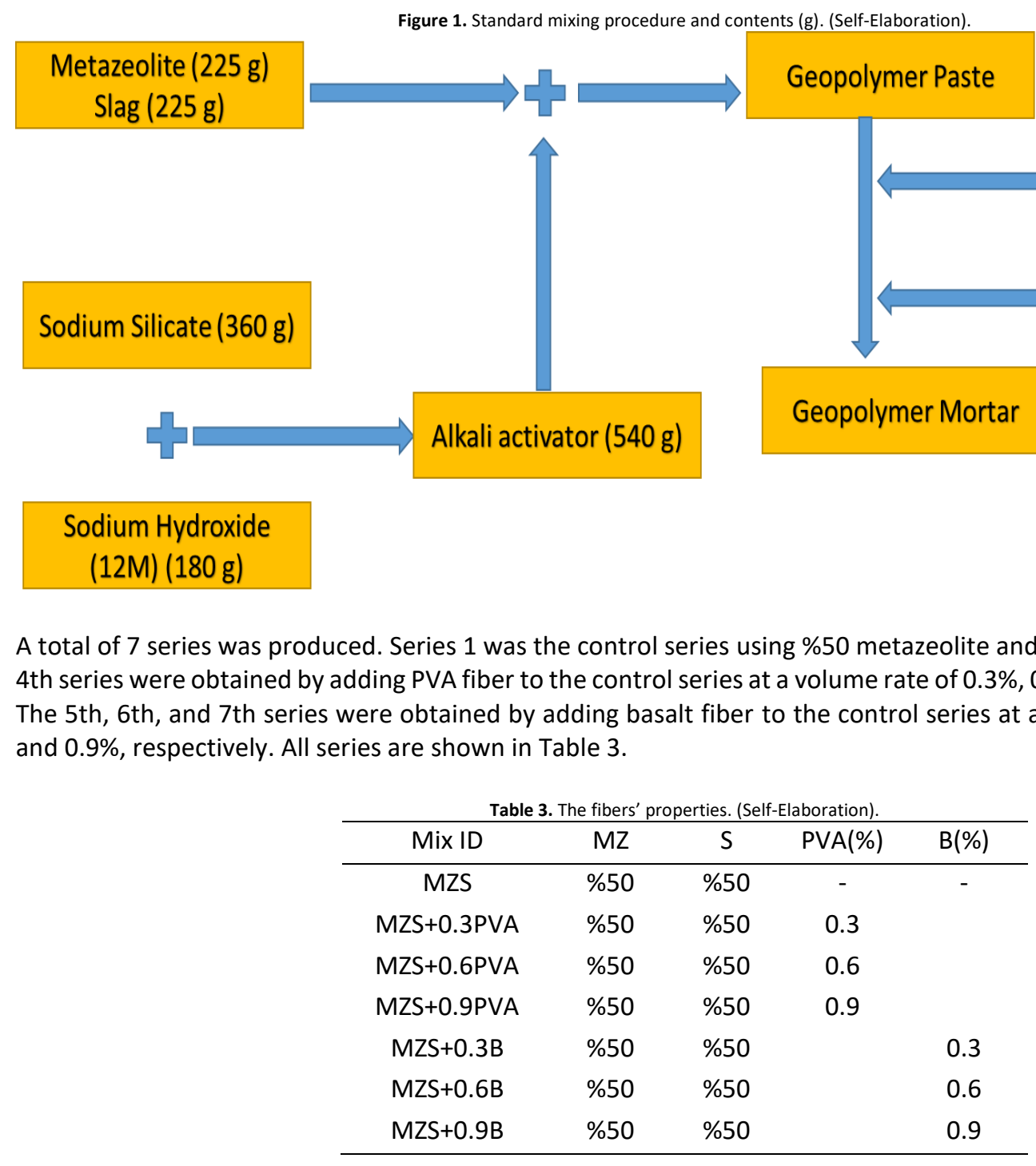

\section{Test procedure}

The high-temperature test $\left(250,500\right.$, and $\left.750{ }^{\circ} \mathrm{C}\right)$ was applied to the 7 series produced after 28 days. After the completion of 28 days, samples were kept in the oven at $105^{\circ} \mathrm{C}$ for 1 day. The high-temperature test was carried out according to the procedure. This standard procedure has been used in different studies (Aygörmez, Canpolat, Almashhadani, et al., 2020; Rashad, 2020). The reason for this was to remove the moisture in the samples and to prevent spillage. Geopolymer samples can be expected to experience some increase in compressive strength due to this situation. However, this strength increase is expected to be low. It is a fact that heat curing is effective on geopolymer mortars. However, the effect of this situation is lower in the following days compared to the first days. Then, the weights of the samples were measured and the samples were placed in the high-temperature oven. The rate of the temperature rise in the high-temperature oven was set at $5^{\circ} \mathrm{C} /$ minute. After reaching the aimed temperature, the samples were held for 1 hour at the desired temperature and the oven door was then opened.

The samples were not removed immediately after the oven door was opened for preventing thermal shock. Then, compressive and flexural strengths, UPV, and weight loss of the samples were determined. While $50 \times 50 \times 50 \mathrm{~mm}$ cube

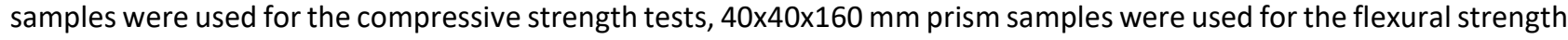
tests. The results were evaluated together with the 28-day results. In each test, three samples were used and the data were determined according to the average of the three samples. XRD, SEM, TGA-DTA, micro-CT, and FT-IR analyzes were carried out for the samples after the testing, in addition to visual inspection. Analyzes were conducted for sample MZS+0.9PVA with the highest mechanical properties pre and post-high temperature. 


\section{Strength results}

Comparison of the 28 -day strength results with the results after the effects of 250,500 , and $750{ }^{\circ} \mathrm{C}$ high temperatures are given in Figures 2 and 3. High curing temperatures resulted in correspondingly high energies. Considering the negative effects of room temperature curing and heat curing, a new curing search was performed and freeze-thaw curing was applied. The shortening of the setting time in the curing at room temperature conditions was achieved by adding slag. With the addition of slag, the $\mathrm{CaO}$ ratio was increased, making the microstructure more homogeneous by making it denser. However, with the formation of CSH/CASH gel, an improvement in mechanical properties occurred (Shinde \& Kadam, 2015). After the samples were held at room temperature conditions for up to 7 days, a freeze-thaw cycle was applied. In this way, it was observed that the compact structure in the geopolymer matrix was strengthened and its reactions were continued.

The humid environment where the freeze-thaw test was conducted here contributed to filling the gaps. Due to these cycles, an advancement process has occurred in the matrix. Thus, binding reaction products continued to form and geopolymerization was provided. In this way, it has continued the curing process. A more detailed explanation of this situation can be made. After the freeze-thaw test, the strength results of hardened mortars are usually expected to decrease. But here, instead of a decrease, an increase occurs. Due to the compact structure of the geopolymer, almost no freeze-thaw degradation occurs, as water cannot enter between dense and compressed plates in low cycles. Also, the formation of geopolymeric products by the freeze-thaw test is increasing. Improvement in concrete and mortar properties has been achieved due to humid conditions. This situation is based on the activation of raw materials (slag, metakaolin, etc.).

This, in turn, counteracts the effect of a freeze attack while creating binding products. Thus, slag activation continued in the humid environment of the test, resulting in the formation of a significant amount of reaction products that increased strength. Also, the freezing temperature of alkali metal solutions in the range of about $-15^{\circ} \mathrm{C}$ and $-20^{\circ} \mathrm{C}$ has increased the resistance of slag-based geopolymers against negative temperatures. Because of this situation, it is necessary to adjust the beginning of freeze-thaw tests of geopolymers containing raw materials such as slag, especially with low reaction kinetics. So, geopolymer mortars provide an increase in strength in low cycles. But in high cycles, this situation reverses and strength decreases. In this study, using this advantage, the low cycle freeze-thaw test was applied as a curing method (Aygörmez, Canpolat, Al-mashhadani, et al., 2020; Puertas et al., 2003; Yunsheng et al., 2008). In a sense, keeping the samples at $105^{\circ} \mathrm{C}$ for 1 day before applying the high-temperature test is a curing application. This situation creates a slight increase in strength results.

However, if it is exposed to high temperatures again, this situation in the strength results is replaced by a decrease. There are conflicting results in the literature on the effect of high temperatures on geopolymer mortars. Some studies showed an increase in strength results in the range of $200-400{ }^{\circ} \mathrm{C}$, while a decrease was observed in some studies. In previous studies, it has been reported that the behavior of geopolymer mortars with the effect of thermal loads depends on curing conditions (Nasr et al., 2018; Türker et al., 2016), activator type (Cheng \& Chiu, 2003), and activator concentration (Nasr et al., 2018; Rashad et al., 2016). In this study, the strength results decreased after the elevated temperature test was performed. The main reasons for this situation were water evaporation and dehydration caused by thermal reactions above $500^{\circ} \mathrm{C}$ (Zhang et al., 2012). In order to better explain the loss of strength above $500^{\circ} \mathrm{C}$, the concept of the steam effect should be explained. The concept of the steam effect was the major reason for the strength loss with increasing high temperatures.

Existing water in the geopolymer matrix turned into steam together with heating. The temperature increase above $100^{\circ} \mathrm{C}$ also caused internal pressure to increase constantly. With the vapor pressure reaching the maximum limit, the geopolymer matrix became dense with less permeability. In this way, the resistance against the high thermal effects occurring within the structure was reduced. Thus, it caused thermal cracks on the surfaces of the samples. The mass loss occurred when the water evaporated from the geopolymer matrix. The loss of mass, which created cracks caused by thermal shrinkage, also led to the loss of strength. Also, with the increasing temperature, a significant thermal mismatch occurred between the aggregate and the geopolymer paste, which triggered micro-cracks in the interface transition area (Jiang et al., 2020). Also, crystallization in the aluminosilicate gel structure occurred more with high temperatures, causing crystallization stress and thermochemical decomposition of crystal lattices. While the recrystallization process had a positive effect on strength and ductility, inhomogeneous recrystallization, which adversely affected this situation, caused a thermal mismatch. 
This was another reason that triggered the formation of microcracks. Despite these conditions, it was found that thermal cracks and fragmentation were limited due to the geopolymers' ability to dissipate heat quickly and to be exposed to less thermal gradients. So, it can be shown that the geopolymer matrix maintained its stability under the influence of high temperatures if the room temperature and freeze-thaw curing cooperated. The drop in flexural strength was higher with the growth of the porous structure and the increase in crack propagation with the high-temperature effect (Zhang et al., 2016). The ranking of test results after high temperatures was found to be similar to that before the experiment. The results increased with the PVA and basalt fibers' effects. The increase in fiber ratios was parallel to the improvement in mechanical properties. PVA and basalt fibers were shown to systematically improve performance while preserving their post-temperature structure and mechanical integrity.

This situation can be explained in more detail. The addition of fibers changed the workability features of geopolymer mortars before the high-temperature test. The workability of metazeolite and slag-based geopolymer was reduced by the addition of fiber. The slump flow value of the non-fibrous sample was $205 \mathrm{~mm}$ and was $194 \mathrm{~mm}, 187 \mathrm{~mm}$, and 176 $\mathrm{mm}$, respectively, in the basalt fiber series of $0.3 \%, 0.6 \%$, and $0.9 \%$, while in the PVA fiber series of $0.3 \%, 0.6 \%$, and $0.9 \%$, it was $179 \mathrm{~mm}, 154 \mathrm{~mm}$ and $132 \mathrm{~mm}$. However, the reduction in workability with the addition of fibers was positively reflected by increasing the shape stability and formability of fiber-reinforced geopolymer mortars. This helped maintain stability after high temperatures (Ranjbar \& Zhang, 2020). The fine dispersion and homogeneous structure of the crystal phases in fibrous materials increased improvements in the mechanical properties. The addition of a nucleating agent, such as $\mathrm{P}_{2} \mathrm{O}_{5}, \mathrm{TiO}_{2}$, or $\mathrm{ZrO}_{2}$, strengthened the microstructure.

Also, basalt fibers provided an important advantage by spontaneously producing a natural nucleator, such as $\mathrm{Fe}_{3} \mathrm{O}_{4}$, during the melting of basaltic rocks (Sim et al., 2005). After $750^{\circ} \mathrm{C}$, the PVA fiber sample increased its compressive strength in the range of $11 \%-38 \%$ compared to the control sample, while the basalt fiber samples created an increase in the range of $8 \%-33 \%$. Melting of PVA fibers in the range of $200-250{ }^{\circ} \mathrm{C}$ played a role in the increased resistance to high temperature. Melted PVA fibers created channels for the steam to escape. Also, PVA fibers prevented the sample from exploding by creating extra paths to allow evaporated moisture to escape without causing high internal pressure (Sahmaran et al., 2010). This study is compatible with previous studies where PVA fibers increased strength more than basalt fibers (Arslan et al., 2019; Celik et al., 2018). The fibers showed similar behavior in flexural strength. The high modulus of elasticity of the fibers provided a better degree of bonding with the geopolymer matrix and post-crack ductility. This is compatible with the literature (Al-mashhadani et al., 2018).

Figure 2. Residual compressive strengths after high-temperature effects. (Self-Elaboration).

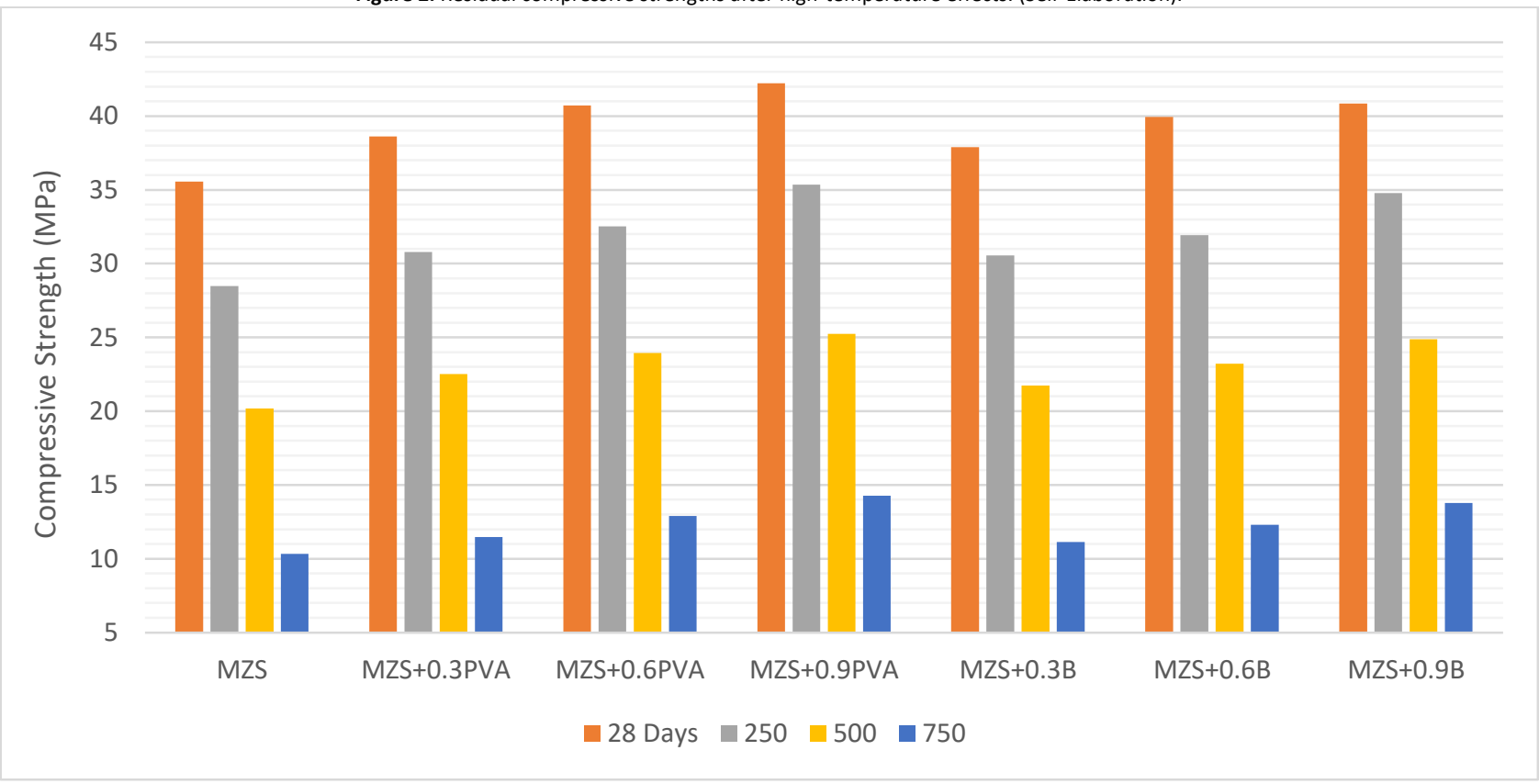


Figure 3. Residual flexural strengths after high-temperature effects. (Self-Elaboration).

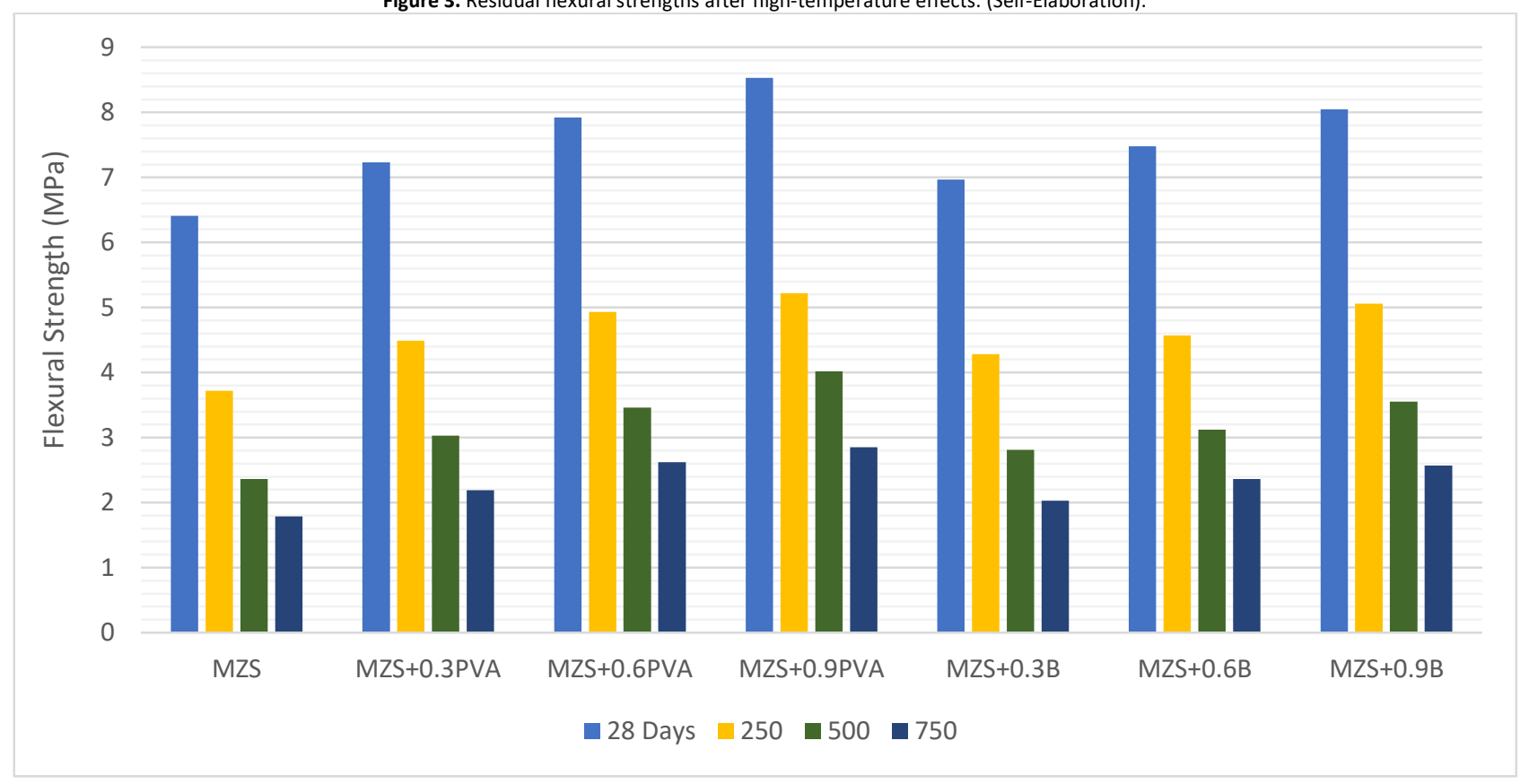

UPV and weight loss results

The UPV test was applied to determine the alterations in the homogeneity of geopolymer samples by a non-destructive method. In Figure 4, UPV results after high temperatures are given along with the 28-day results. If the results were analyzed in general, they were parallel with the strength results. UPV results were lower than the conditions where high curing temperatures were applied, due to the low dissolution of binding materials caused by curing at room temperature. Nevertheless, the freeze-thaw curing, together with the compact structure, played a role in enhancing the UPV results. The moist environment created by the experimental conditions helped to fill the voids (Yunsheng et al., 2008).

After the high-temperature effect, this compact structure was shown considerable resistance. As the temperature effect increased, the water evaporation increased and the pore structure grew. The mass loss also triggered additional gap formation. This situation led to a drop in UPV values. Also, it was seen that the density of composites decreased due to micro-cracks caused by temperature. Due to this situation, the propagation time of ultrasonic velocity waves was longer and there were decreases in UPV values (Topçu \& Karakurt, 2008). The increase in crack propagation above $500^{\circ} \mathrm{C}$ and the start of the melting of the fibers extended the propagation process of ultrasonic velocity waves, resulting in lower values. However, the high modulus of elasticity of PVA and basalt fibers limited this situation (Arslan et al., 2019; Celik et al., 2018).

With the application of high temperatures, weight losses increased. The weight losses that occurred with high temperatures are shown in Figure 5. With the high-temperature effect, the dehydration mechanism formed in the matrix structure, and the existing moisture in the structure moved away, towards the outer surface. These situations caused internal damage and weight loss to the microstructure. If the stages formed were examined, it can be considered as three stages. In the first stage, physisorbed water loss occurred between $30-210{ }^{\circ} \mathrm{C}$, while polymer side chains deteriorated between 210 and $400^{\circ} \mathrm{C}$. Between 400 and $500^{\circ} \mathrm{C}$, disruptions began to occur in the main polymer chains. These conditions triggered weight loss. In particular, the reactions of the fibers and the matrix interface above $500^{\circ} \mathrm{C}$ led to increased distortion. Despite this situation, when weight losses were examined, PVA and basalt fibers were shown to reduce weight losses. In this way, the performance of the geopolymer mortars also increased. A brittle fracture and reduced engineering properties were observed with temperature (Masi et al., 2015). 

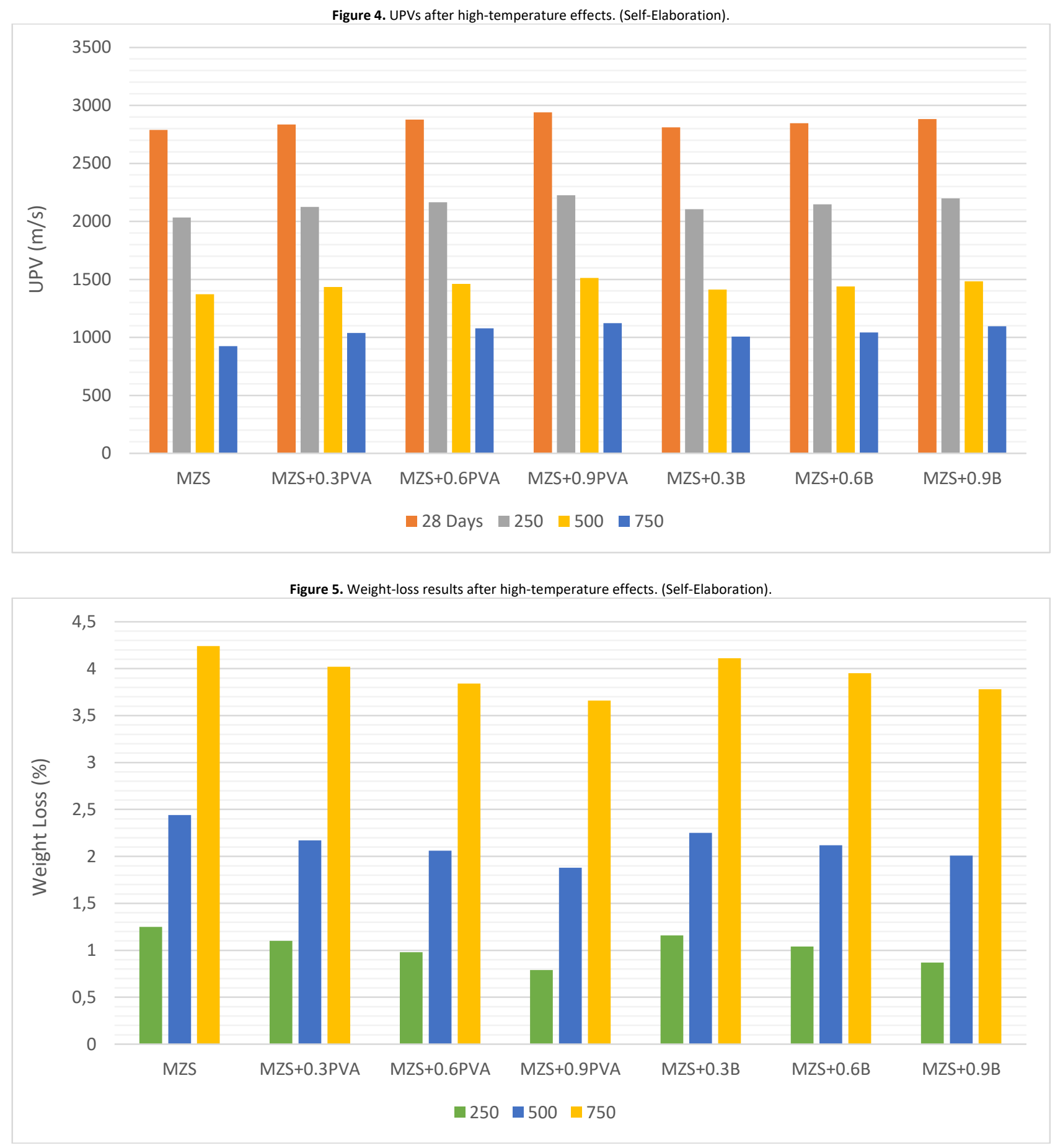

\section{Visual inspection and analyses}

After the test was completed, the surface changes were examined (Figure 6); a visual inspection was carried out 1 hour after the test was completed. In parallel with the strength losses after $750^{\circ} \mathrm{C}$, there were color changes. As there was a tendency of the samples to increase in roughness, a brittle structure began to form. The main reason for these situations was that temperature effects damaged the geopolymeric chains (by breaking the bonds of Si-O-Al). However, despite the high-temperature effect, it was observed that the cracks that formed were limited and the samples remained stable. It was proved that geopolymer samples did not show dispersion, depending on the curing condition applied after hightemperature effects (Arslan et al., 2019; Aygörmez, Canpolat, Al-mashhadani, et al., 2020; Celik et al., 2018). 


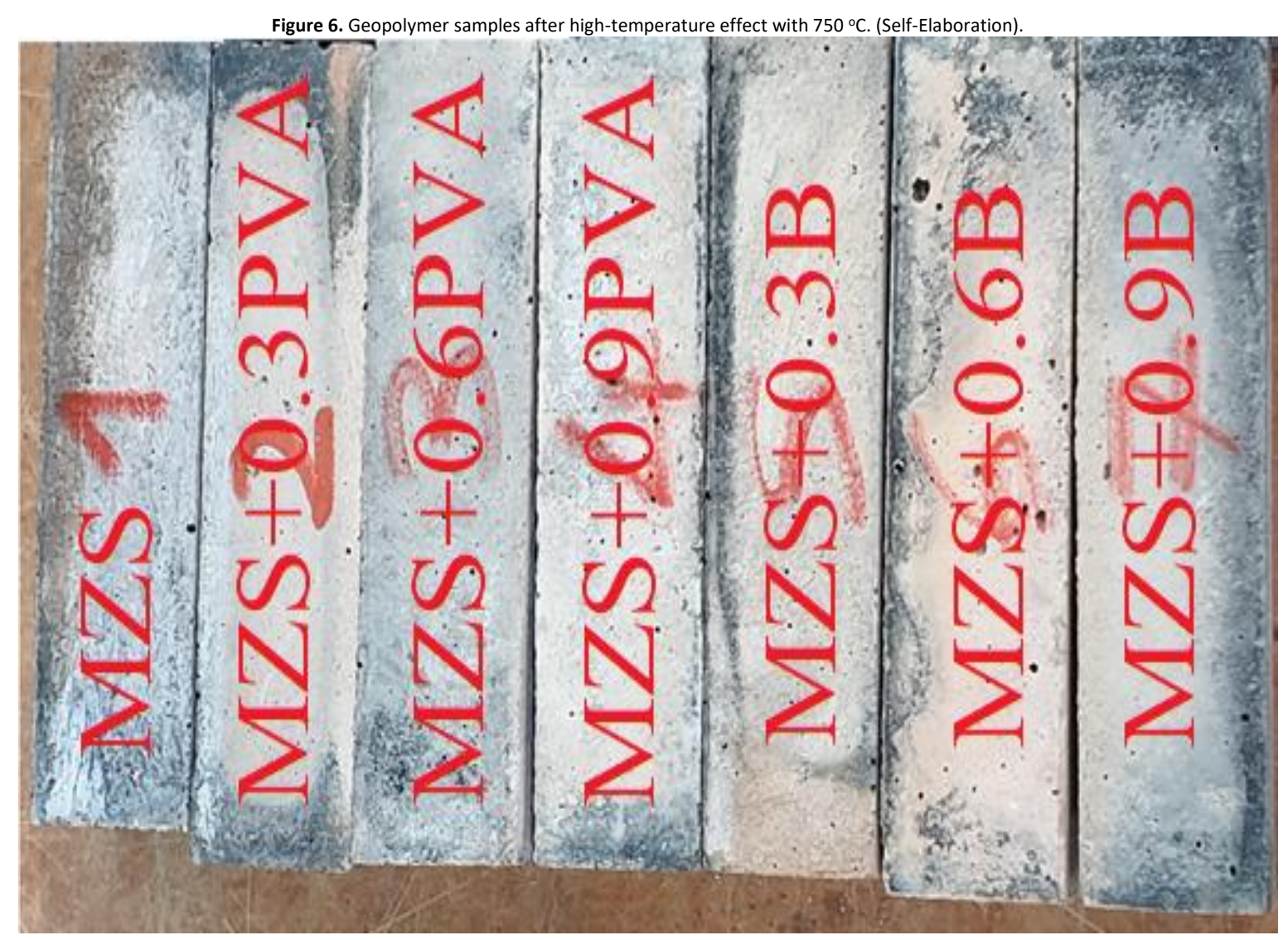

The binding degree of the geopolymer matrix was investigated by SEM analyzes before and after $750^{\circ} \mathrm{C}$ in sample MZS+0.9PVA (Figure 7). The connection between microstructure and strength was investigated with these SEM analyzes. Micro-cracks and microstructural damage occurred in SEM images after the high-temperature effects (Lahoti et al., 2018). The acceleration of structural defects and collapses increased the loss of strength. Internal and surface cracks occurred with a high internal pressure effect. However, it was observed that the micro-cracks formed remained at a low rate. According to the SEM images, it was observed that the PVA fiber melted. However, it melted and created channels, allowing the steam pressure to escape. Also, it caused the formation of limited air voids by creating extra paths without causing internal pressure and preventing the explosion of the sample. Also, the curing method applied ensured that the geopolymer samples were resistant to high temperatures by providing rapid heat dissipation and less exposure to thermal gradients.

This indicated that matrix bonding and continuity were achieved in geopolymerization. Despite these situations, it was observed that the classical geopolymer microstructure was preserved and the homogeneous matrix in the gel was resistant to high-temperature effects following the results found by visual inspection. These situations proved that geopolymer samples were a sustainable, durable product (Arslan et al., 2019; Celik et al., 2018). 
a)
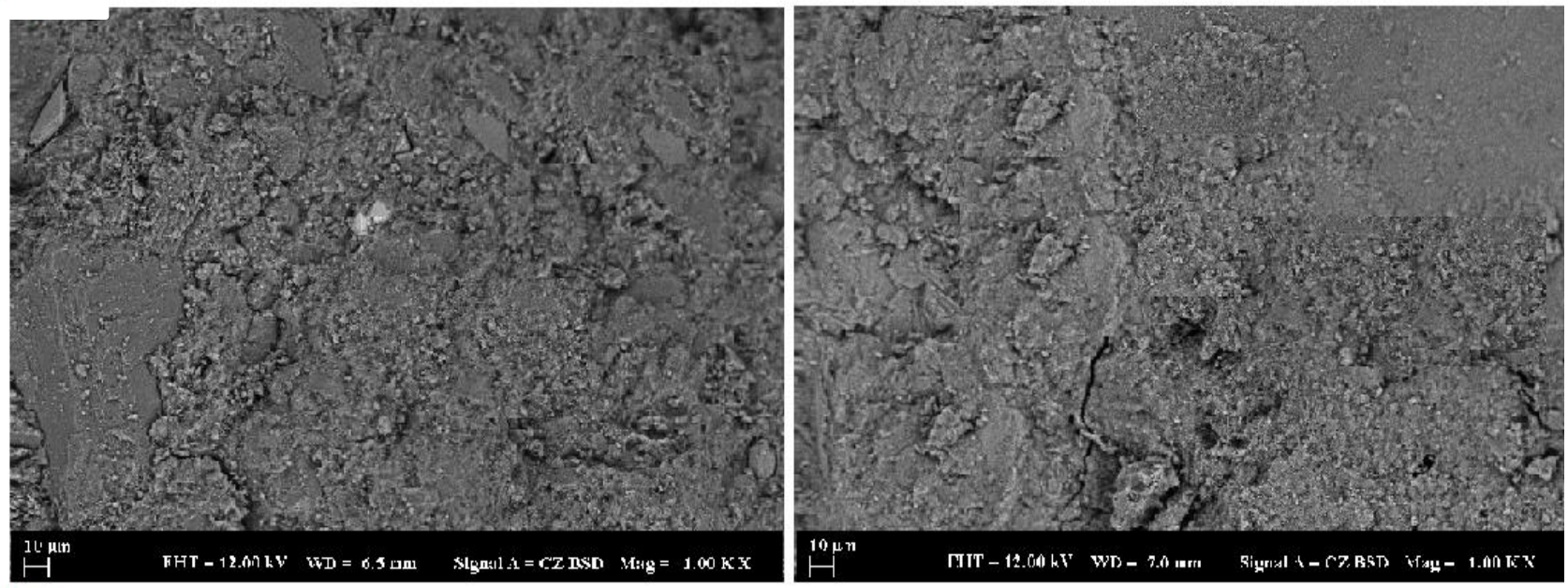

b)
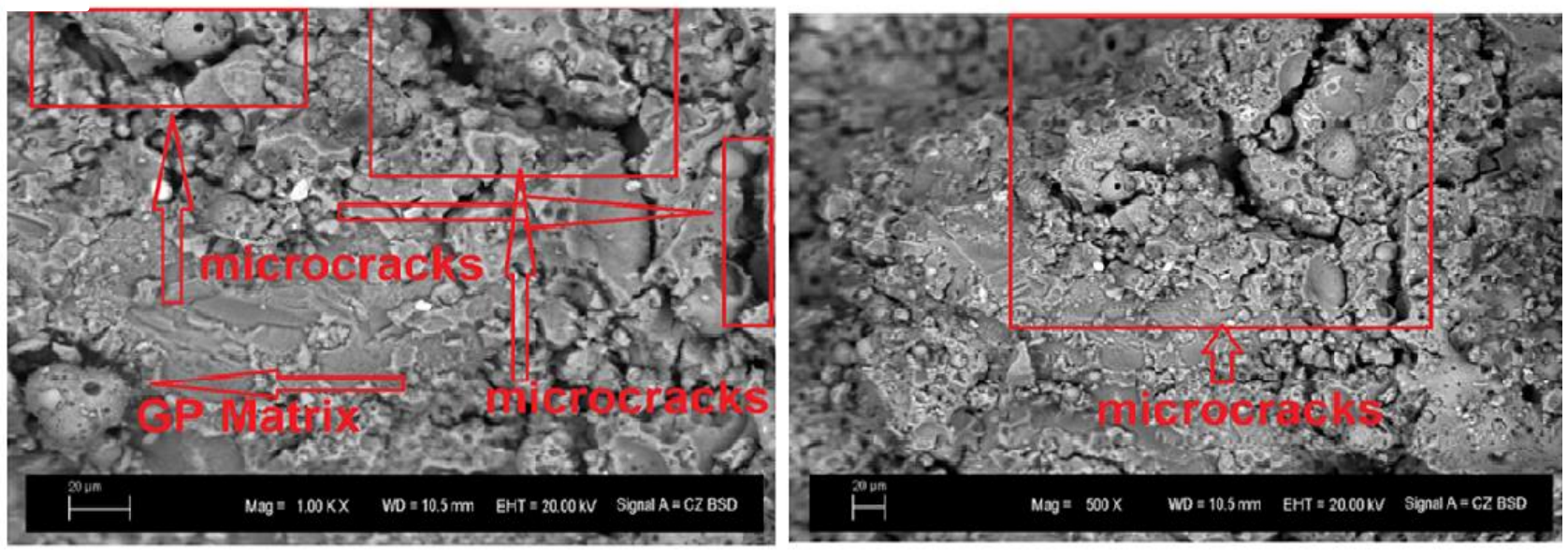

The XRD spectrums of sample MZS+0.9PVA before and after $750^{\circ} \mathrm{C}$ are shown in Figure 8 . It was observed that significant changes occurred during the high-temperature effect. Quartz, mullite, and clinoptilolite were mainly observed in the samples. XRD analysis showed that a semicrystalline structure was formed and some peaks from raw materials were preserved. After exposure to the high-temperature effect, quartz peaks reflecting the typical amorphous gel phase from $27^{\circ}$ to $28^{\circ} 2 \theta$ were observed (Gomez-Zamorano et al., 2016). After the high-temperature effect, crystal components and amorphous phases were examined and the overall structure was preserved despite the decrease in peaks. The basic matrix of the geopolymer sample was resistant to high temperatures.

The geopolymer mechanism ensured the continuity of the polymerization reactions due to the strong aluminosilicate bonds but, as the time elapsed by the high-temperature effect increased, the degradation increased and depolymerization occurred in the aluminosilicate polymers (Rashad, 2015). As was seen in previous studies, a geopolymer had much better high-temperature resistance than conventional concrete (Arslan et al., 2019; Celik et al., 2018). 

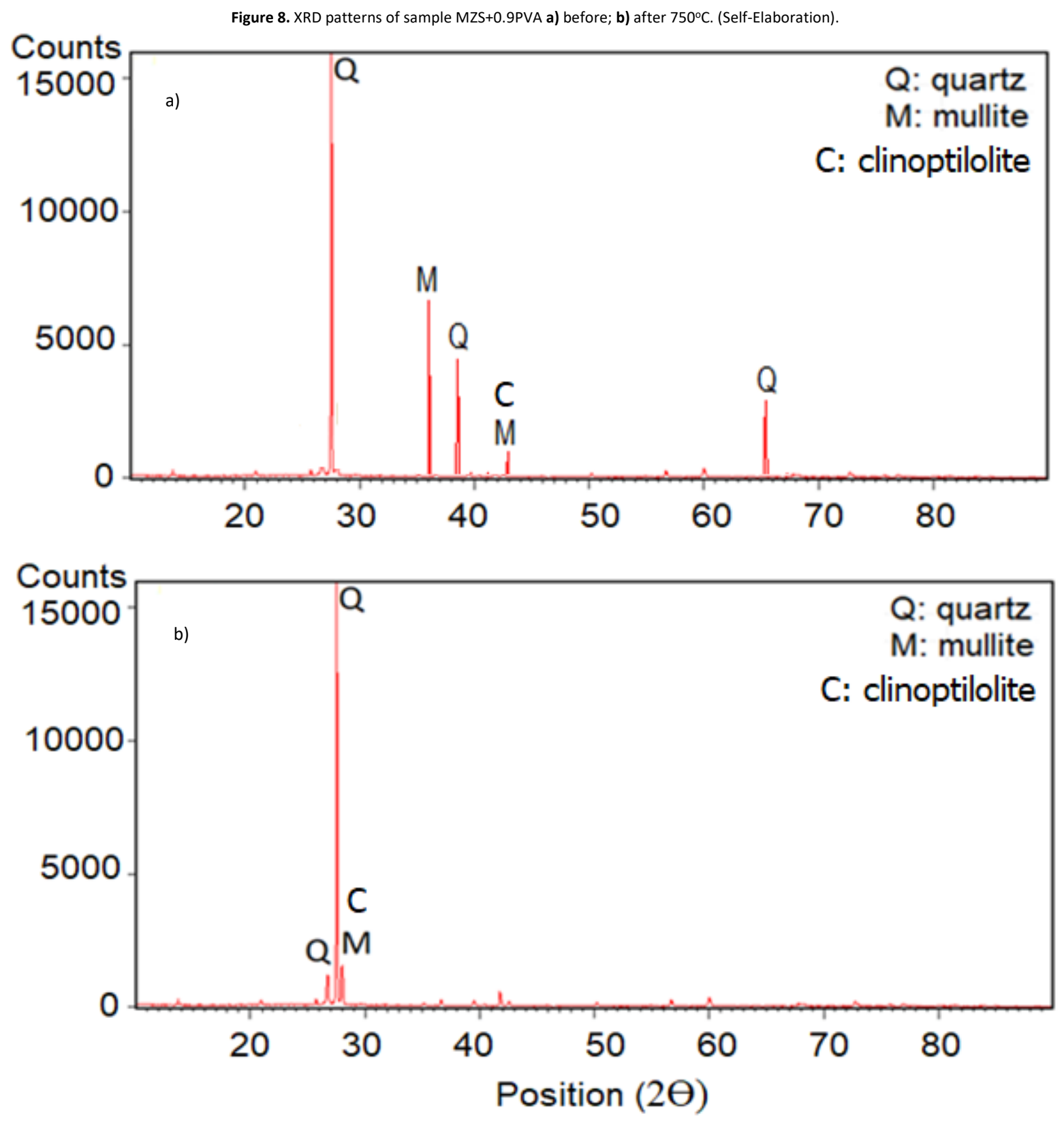

The FT-IR spectrums of sample MZS+0.9PVA before and after $750^{\circ} \mathrm{C}$ are shown in Figure 9 . The wavelength formed at the end of the test was obtained as $1021.37 \mathrm{~cm}^{-1}$ and $995.97 \mathrm{~cm}^{-1}$ before and after the high temperature, respectively. The Si-O-Al bonds showed the asymmetric stretching vibrations, while this bond was indicated by the wavelengths here. When the Si-O-Al bonds were examined before and after the high-temperature test, it was observed that the changes were limited. The post-test band intensity was found to be between 1683.24 and $1323.11 \mathrm{~cm}^{-1}$ before the hightemperature test and between 1652.81 and $1281.38 \mathrm{~cm}^{-1}$ after the high-temperature test (Rocha et al., 2018). 

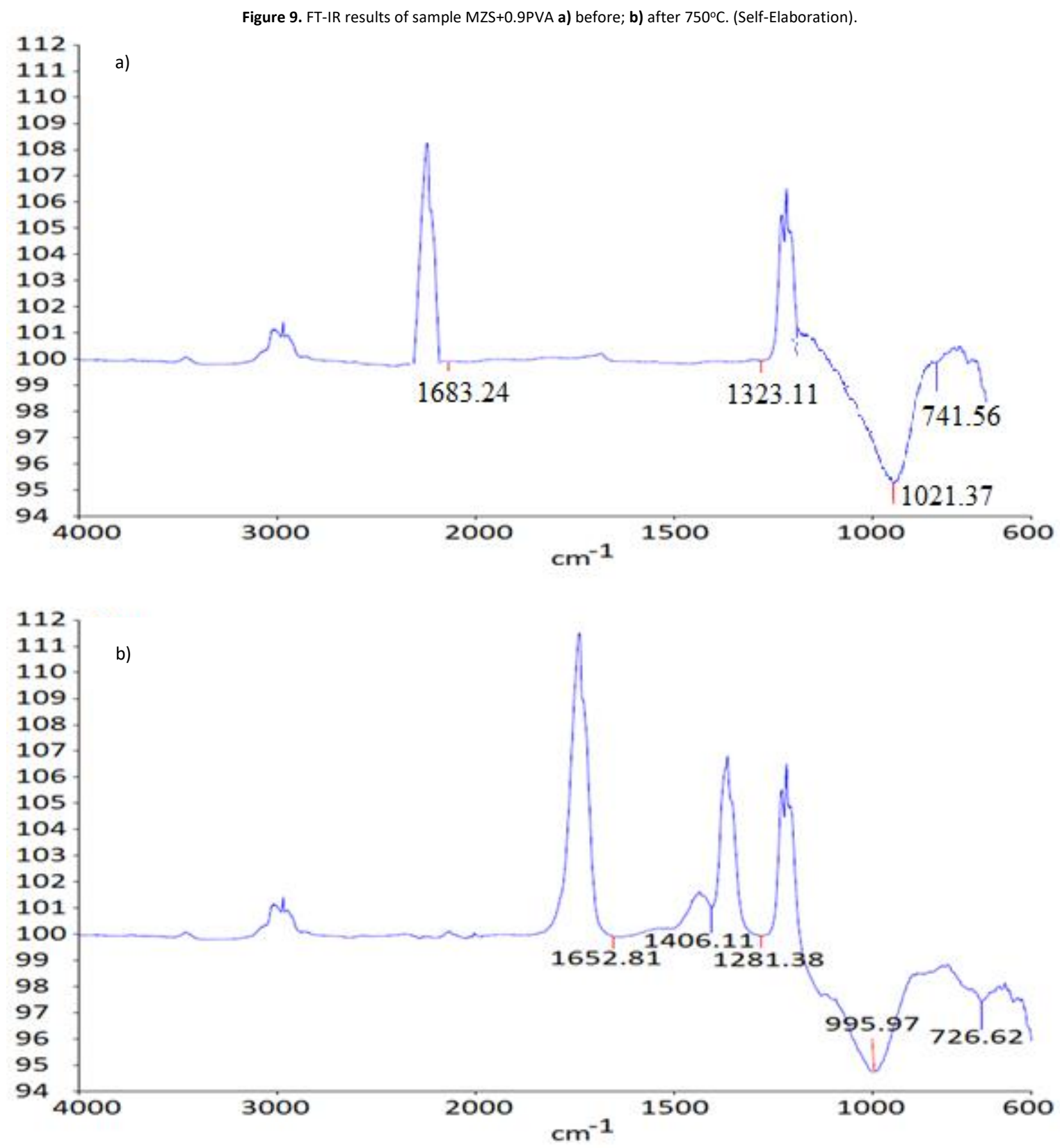

The DTA and TGA curves of sample MZS+0.9PVA before and after $750^{\circ} \mathrm{C}$ are shown in Figure 10 . Blue curves showed weight loss. In sample MZS+0.9PVA, TGA analysis indicated a weight loss of $1.7 \%$ and $5.9 \%$ before and after the high temperature, respectively. The results indicated that the rate increases were limited after high-temperature effects. This exhibited that the geopolymer stability was preserved although the high-temperature effect. The weight loss changes from 0 to $700{ }^{\circ} \mathrm{C}$ were caused by the evaporation of free and bound water in the matrix. Also, endothermic peaks could be seen with DTA curves (Degirmenci, 2018). 

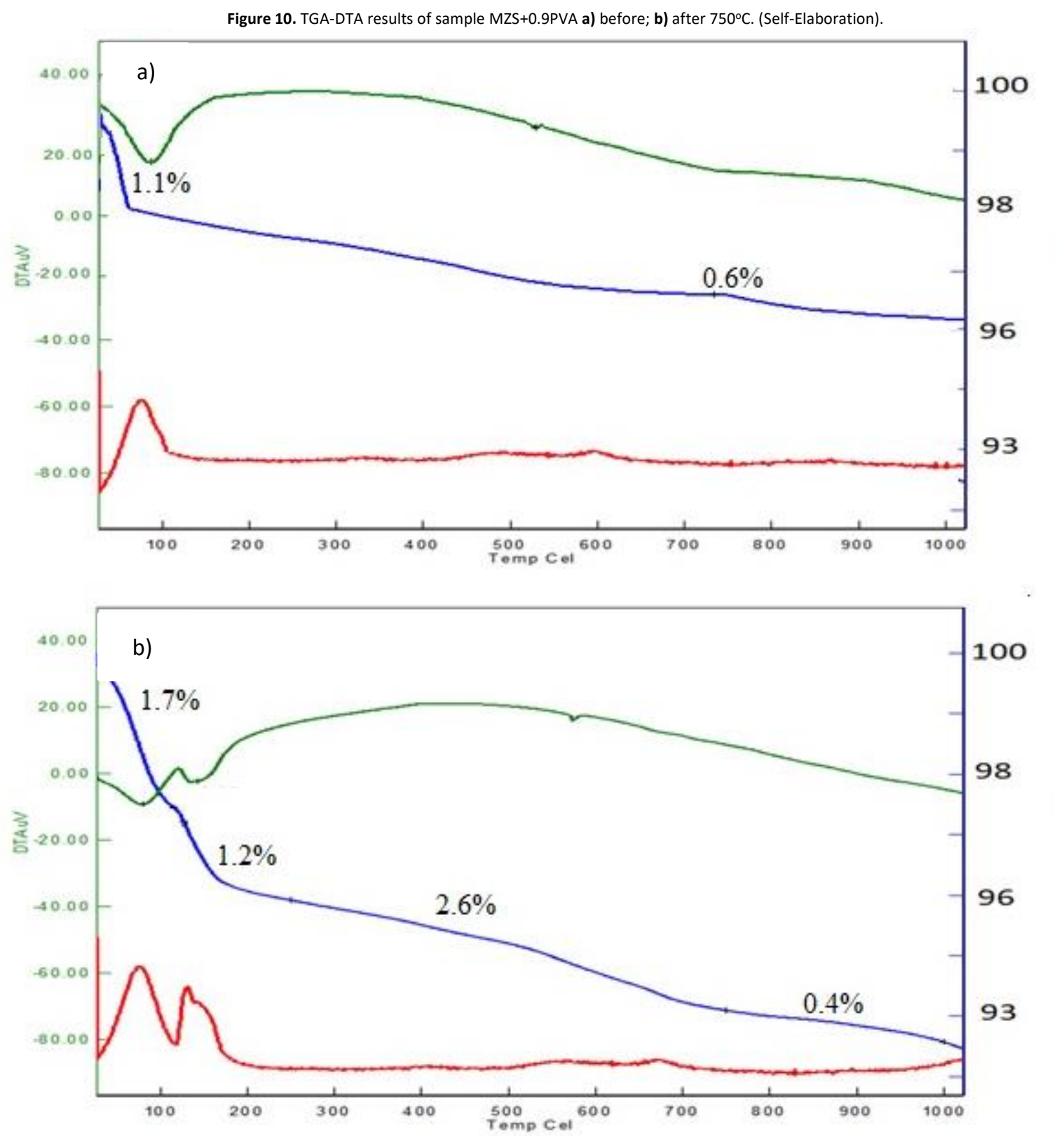

Micro-CT analyzes of sample MZS+0.9PVA before and after the high-temperature effect are shown in Figure 11 . At the end of the analyzes, a representative cross-sectional view was examined. Cracks were formed with the effect of high temperatures. Besides, increasing shrinkage with temperature caused incompatibilities. Incompatibilities played an important role in crack formation. Crack formation brought along the loss of strength. X-ray attenuation produced dark colors. These dark colors corresponded to air voids. Fiber additive limited air voids and cracks. It was observed that geopolymer samples were resistant to high-temperature effects (Aygörmez, Canpolat, Al-mashhadani, et al., 2020). 
Figure 11. Micro-CT images of sample MZS+0.9PVA a) before; b) after $750^{\circ} \mathrm{C}$. (Self-Elaboration).

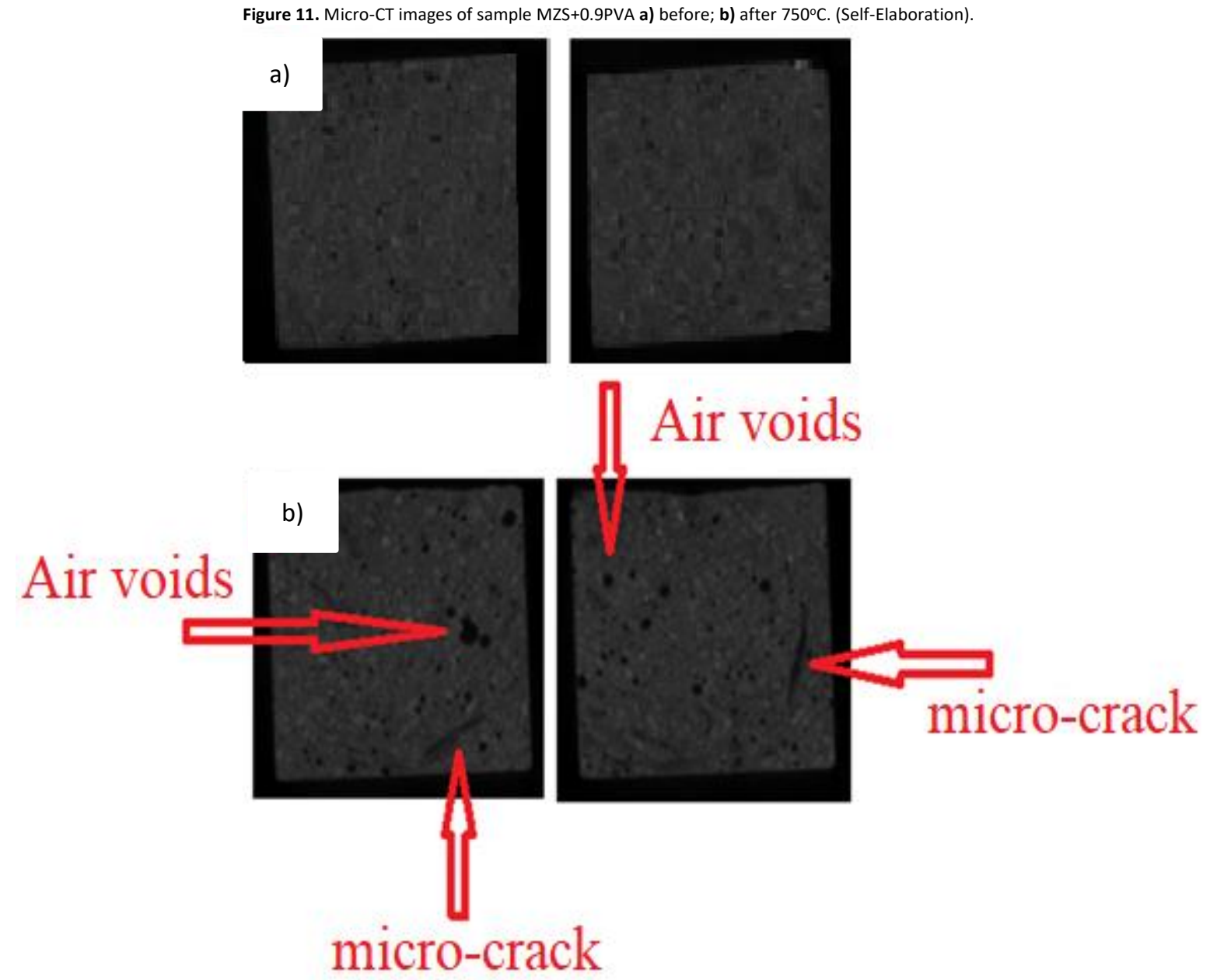

Correlation between UPV and compressive strength

For this study, the evaluation of the correlation properties between UPV and compressive strength results after $750^{\circ} \mathrm{C}$ was investigated (Figure 12). With this method, the consistency of these two features was designated. $\mathrm{R}^{2}$ showed a factor that reflected the correlation degree and indicated a consistent result if there was a value higher than 0.75 . According to the results of this study, this value was 0.90 and the correlation was satisfactory. In general, it was determined that the results had a satisfactory correlation for all samples. These results are compatible with other studies (Ali et al., 2020; Uysal et al., 2018). 
Figure 12. Correlation relationship between compressive strength and UPV after $750^{\circ} \mathrm{C}$. (Self-Elaboration).

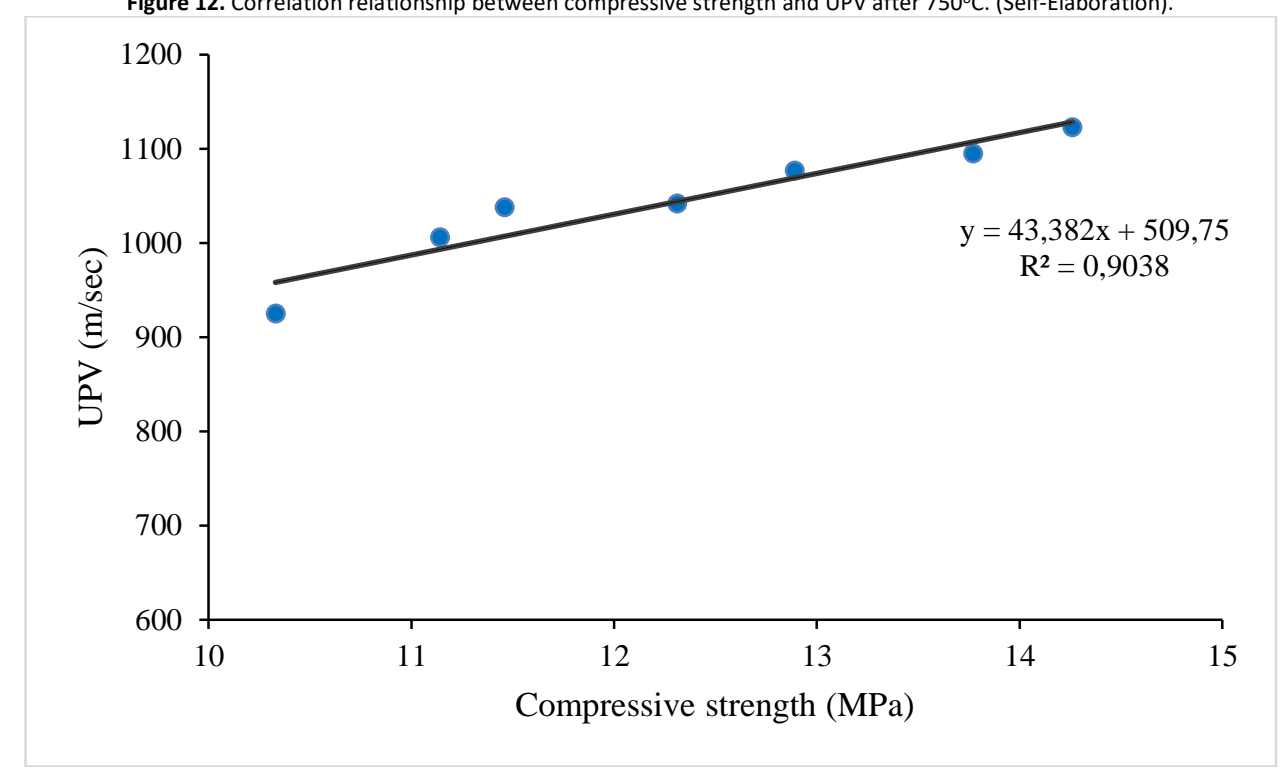

Conclusions

For this paper, the engineering properties for geopolymer specimens using metazeolite and slag after room temperature and freeze-thaw curing were investigated under high-temperature effects and the following results were obtained:

- Metazeolite has the potential to be used in the production of geopolymers such as metakaolin. If heat curing is not applied, using slag in the production of metazeolite-based geopolymer shortens the setting time.

- Due to 7 days of room conditions curing and 21 days of freeze-thaw curing applied as a new method instead of heat curing, it has been possible to produce an environmentally friendly geopolymer. Binding materials such as slag with low activation provided the continuation of geopolymerization by forming binding products due to the moist environment of the freeze-thaw test. In this way, an increase in strength has occurred.

- PVA and basalt fibers have created a more systematic behavior by strengthening the bonds between geopolymer matrices. The fact that fibrous materials have fine crystalline phases and a homogeneous structure has provided an improvement in mechanical properties. Since PVA fibers formed stronger bonds than basalt fibers, the results were higher. Increased fiber content has a positive effect on strength results. According to the data obtained, the highest results were in samples MZS+0.9PVA and MZS+0.9B, while the lowest result was in sample MZS.

- Deformations occurred in the mechanical properties of geopolymer composites due to the high-temperature effects. It was observed that the geopolymer samples preserved their stability against the $750^{\circ} \mathrm{C}$ temperature effect with the new curing method applied. With this curing effect, rapid heat dissipation capacity and exposure to fewer thermal gradients were preserved. This result was supported by the analyzes and visual inspection.

- The improvements caused by the fibers in the mechanical properties of geopolymer samples before high temperature were effective after high temperatures. Although PVA fibers melted, they increased the mechanical properties compared to the control sample by creating channels that would help the evaporated moisture escape without causing high internal pressure. 
Al-mashhadani, M. M., Canpolat, O., Aygörmez, Y., Uysal, M., \& Erdem, S. (2018). Mechanical and microstructural characterization of fiber reinforced fly ash based geopolymer composites. Construction and Building Materials, 167, 505-513. https://doi.org/10.1016/j.conbuildmat.2018.02.061

Ali, N., Canpolat, O., Aygörmez, Y., \& Al-Mashhadani, M. M. (2020). Evaluation of the 12-24 mm basalt fibers and boron waste on reinforced metakaolin-based geopolymer. Construction and Building Materials, 251, 118976. https://doi.org/10.1016/j.conbuildmat.2020.118976

Amuthakkannan, P., Manikandan, V., Winowlin Jappes, J. T., \& Uthayakumar, M. (2013). Effect of fibre length and fibre content on mechanical properties of short basalt fibre reinforced polymer matrix composites. Materials Physics and Mechanics, 16(2), 107-117.

Arslan, A. A., Uysal, M., Yılmaz, A., Al-mashhadani, M. M., Canpolat, O., Şahin, F., \& Aygörmez, Y. (2019). Influence of wetting-drying curing system on the performance of fiber reinforced metakaolin-based geopolymer composites. Construction and Building Materials, 225, 909-926. https://doi.org/10.1016/j.conbuildmat.2019.07.235

Assaedi, H., Alomayri, T., Shaikh, F. U. A., \& Low, I. M. (2015). Characterisation of mechanical and thermal properties in flax fabric reinforced geopolymer composites. Journal of Advanced Ceramics, 4(4), 272-281. https://doi.org/10.1007/s40145-015-0161-1

Aygörmez, Y., Canpolat, O., \& Al-mashhadani, M. M. (2020a). A survey on one year strength performance of reinforced geopolymer composites. Construction and Building Materials, 264, 120267. https://doi.org/10.1016/j.conbuildmat.2020.120267

Aygörmez, Y., Canpolat, O., \& Al-mashhadani, M. M. (2020b). Assessment of geopolymer composites durability at one year age. Journal of Building Engineering, 32, 101453. https://doi.org/10.1016/j.jobe.2020.101453

Aygörmez, Y., Canpolat, O., Al-mashhadani, M. M., \& Uysal, M. (2020). Elevated temperature, freezing-thawing and wetting-drying effects on polypropylene fiber reinforced metakaolin based geopolymer composites. Construction and Building Materials, 235. https://doi.org/10.1016/j.conbuildmat.2019.117502

Barbosa, V. F. F., \& MacKenzie, K. J. D. (2003). Thermal behaviour of inorganic geopolymers and composites derived from sodium polysialate. Materials Research Bulletin, 38(2), 319-331. https://doi.org/10.1016/S0025-5408(02)01022-X

Bhushan H. Shinde, \& Dr. Kshitija N. Kadam. (2015). Properties of Fly Ash based Geopolymer Mortar. International Journal of Engineering Research And, 4(7), 203-206. https://doi.org/10.17577/ijertv4is070750

Billong, N., Kinuthia, J., Oti, J., \& Melo, U. C. (2018). Performance of sodium silicate free geopolymers from metakaolin (MK) and Rice Husk Ash (RHA): Effect on tensile strength and microstructure. Construction and Building Materials, 189, 307-313. https://doi.org/10.1016/j.conbuildmat.2018.09.001

Bingöl, Ş., Bilim, C., Atiş, C. D., \& Durak, U. (2020). Durability Properties of Geopolymer Mortars Containing Slag. Iranian Journal of Science and Technology - Transactions of Civil Engineering, 44(Supppl 1), 561-569. https://doi.org/10.1007/s40996-019-00337-0

Burciaga-Díaz, O., Gómez-Zamorano, L. Y., \& Escalante-García, J. I. (2016). Influence of the long term curing temperature on the hydration of alkaline binders of blast furnace slag-metakaolin. Construction and Building Materials, 113, 917-926. https://doi.org/10.1016/j.conbuildmat.2016.03.111

Celik, A., Yilmaz, K., Canpolat, O., Al-mashhadani, M. M., Aygörmez, Y., \& Uysal, M. (2018). High-temperature behavior and mechanical characteristics of boron waste additive metakaolin based geopolymer composites reinforced with synthetic fibers. Construction and Building Materials, 187, 1190-1203. https://doi.org/10.1016/j.conbuildmat.2018.08.062

Cheng, T. W., \& Chiu, J. P. (2003). Fire-resistant geopolymer produce by granulated blast furnace slag. Minerals Engineering, 16(3), $205-210$. https://doi.org/10.1016/S0892-6875(03)00008-6

Davidovits, J., \& Sawyer, J. L. (1985). U.S. Patent No. 4,509,985. Washington, DC: U.S. Patent and Trademark Office.

Davidovits, J. (2008). Geopolymer Chemistry and Applications, 5th edition. Saint-Quentin, France: Joseph Davidovits (Issue January 2008). Available on: https://www.researchgate.net/publication/265076752

Degirmenci, F. N. (2018). Freeze-Thaw and fire resistance of geopolymer mortar based on natural and waste pozzolans. Ceramics - Silikaty, 62(1), 4149. https://doi.org/10.13168/cs.2017.0043

Dias, D. P., \& Thaumaturgo, C. (2005). Fracture toughness of geopolymeric concretes reinforced with basalt fibers. Cement and Concrete Composites, 27(1), 49-54. https://doi.org/10.1016/j.cemconcomp.2004.02.044

Dombrowski, K., Buchwald, A., \& Weil, M. (2007). The influence of calcium content on the structure and thermal performance of fly ash based geopolymers. Journal of Materials Science, 42(9), 3033-3043. https://doi.org/10.1007/s10853-006-0532-7

Duan, P., Yan, C., \& Zhou, W. (2017). Compressive strength and microstructure of fly ash based geopolymer blended with silica fume under thermal cycle. Cement and Concrete Composites, 78, 108-119. https://doi.org/10.1016/j.cemconcomp.2017.01.009

Duxson, P., Fernández-Jiménez, A., Provis, J. L., Lukey, G. C., Palomo, A., \& Van Deventer, J. S. J. (2007). Geopolymer technology: The current state of the art. Journal of Materials Science, 42(9), 2917-2933. https://doi.org/10.1007/s10853-006-0637-z

Gomez-Zamorano, L. Y., Vega-Cordero, E., \& Struble, L. (2016). Composite geopolymers of metakaolin and geothermal nanosilica waste. Construction and Building Materials, 115, 269-276. https://doi.org/10.1016/j.conbuildmat.2016.03.002

Heah, C. Y., Kamarudin, H., Mustafa Al Bakri, A. M., Binhussain, M., Luqman, M., Khairul Nizar, I., Ruzaidi, C. M., \& Liew, Y. M. (2011). Effect of curing profile on kaolin-based geopolymers. Physics Procedia, 22, 305-311. https://doi.org/10.1016/j.phpro.2011.11.048 
Jalilifar, H., Sajedi, F., \& Toosi, V. R. (2020). Evaluating the durability of recycled concrete made of coarse recycled aggregate concrete containing silicafume and natural zeolite. Revista de La Construccion, 19(3), 457-473. https://doi.org/10.7764/RDLC.19.3.457

Jaya, N. A., Yun-Ming, L., Cheng-Yong, H., Abdullah, M. M. A. B., \& Hussin, K. (2020). Correlation between pore structure, compressive strength and thermal conductivity of porous metakaolin geopolymer. Construction and Building Materials, 247 , 118641. https://doi.org/10.1016/j.conbuildmat.2020.118641

Jiang, X., Xiao, R., Zhang, M., Hu, W., Bai, Y., \& Huang, B. (2020). A laboratory investigation of steel to fly ash-based geopolymer paste bonding behavior after exposure to elevated temperatures. Construction and Building Materials, 254 119267. https://doi.org/10.1016/j.conbuildmat.2020.119267

Lahoti, M., Wong, K. K., Yang, E. H., \& Tan, K. H. (2018). Effects of Si/Al molar ratio on strength endurance and volume stability of metakaolin geopolymers subject to elevated temperature. Ceramics International, 44(5), 5726-5734. https://doi.org/10.1016/j.ceramint.2017.12.226

Masi, G., Rickard, W. D. A., Bignozzi, M. C., \& Van Riessen, A. (2015). The effect of organic and inorganic fibres on the mechanical and thermal properties of aluminate activated geopolymers. Composites Part B: Engineering, 76, $218-228$. https://doi.org/10.1016/j.compositesb.2015.02.023

Nasr, D., Pakshir, A. H., \& Ghayour, H. (2018). The influence of curing conditions and alkaline activator concentration on elevated temperature behavior of alkali activated slag (AAS) mortars. Construction and Building Materials, 190, 108-119. https://doi.org/10.1016/j.conbuildmat.2018.09.099

Nikolov, A., Rostovsky, I., Nugteren, H. (2017). Natural and calcined zeolite (metazeolite) based geopolymers. BULGARIAN GEOLOGICAL SOCIETY, National Conference with International Participation "GEOSCIENCES 2017," Sofía, Bulgaria, January, 31-32. Available on: https://www.researchgate.net/publication/321769385_Natural_and_calcined_zeolite_metazeolite_based_geopolymers_Geopolimeri_na_osn ovata_na_priroden_i_kalciniran_zeolit_metazeolit/citations

Nikolov, A., Nugteren, H., \& Rostovsky, I. (2020). Optimization of geopolymers based on natural zeolite clinoptilolite by calcination and use of aluminate activators. Construction and Building Materials, 243, 118257. https://doi.org/10.1016/j.conbuildmat.2020.118257

Nikolov, A., \& Rostovsky, I. (2017). Sodium-silicate geopolymers based on natural zeolite - clinoptilolite. Comptes Rendus de L'Academie Bulgare Des Sciences, 70(12), 1655-1662.

Özen, S., \& Alam, B. (2018). Compressive strength and microstructural characteristics of natural zeolite-based geopolymer. Periodica Polytechnica Civil Engineering, 62(1), 64-71. https://doi.org/10.3311/PPci.10848

Pan, Z., Tao, Z., Murphy, T., \& Wuhrer, R. (2017). High temperature performance of mortars containing fine glass powders. Journal of Cleaner Production, 162, 16-26. https://doi.org/10.1016/j.jclepro.2017.06.003

Provis, J. L. (2014). Geopolymers and other alkali activated materials: Why, how, and what? Materials and Structures/Materiaux et Constructions, 47(1-2), 11-25. https://doi.org/10.1617/s11527-013-0211-5

Puertas, F., Amat, T., Fernández-Jiménez, A., \& Vázquez, T. (2003). Mechanical and durable behaviour of alkaline cement mortars reinforced with polypropylene fibres. Cement and Concrete Research, 33(12), 2031-2036. https://doi.org/10.1016/S0008-8846(03)00222-9

Ranjbar, N., \& Zhang, M. (2020). Fiber-reinforced geopolymer composites: A review. Cement and Concrete Composites, 107, 103498. https://doi.org/10.1016/j.cemconcomp.2019.103498

Rashad, A. M. (2015). An exploratory study on sodium sulphate-activated slag blended with Portland cement under the effect of thermal loads. Journa of Thermal Analysis and Calorimetry, 119(3), 1535-1545. https://doi.org/10.1007/s10973-014-4345-7

Rashad, A. M. (2020). An investigation on alkali-activated slag pastes containing quartz powder subjected to elevated temperatures. Revista de La Construcción, 2015, 42-51. https://doi.org/10.7764/rdlc.19.1.42-51

Rashad, A. M., Zeedan, S. R., \& Hassan, A. A. (2016). Influence of the activator concentration of sodium silicate on the thermal properties of alkaliactivated slag pastes. Construction and Building Materials, 102, 811-820. https://doi.org/10.1016/j.conbuildmat.2015.11.023

Rivera, J. F., De Gutierrez, R. M., Mejia, J. M., \& Gordillo, M. (2014). Hybrid cement based on the alkali activation of by-products of coal. Revista de La Construccion, 13(2), 31-39. https://doi.org/10.4067/s0718-915×2014000200004

Rocha, T. da S., Dias, D. P., França, F. C. C., Guerra, R. R. de S., \& Marques, L. R. da C. de O. (2018). Metakaolin-based geopolymer mortars with different alkaline activators ( $\mathrm{Na}+$ and $\mathrm{K}+$ ). Construction and Building Materials, 178, 453-461. https://doi.org/10.1016/j.conbuildmat.2018.05.172

Rovnaník, P. (2010). Effect of curing temperature on the development of hard structure of metakaolin-based geopolymer. Construction and Building Materials, 24(7), 1176-1183. https://doi.org/10.1016/j.conbuildmat.2009.12.023

Sahmaran, M., Lachemi, M., \& Li, V. C. (2011). Assessing Mechanical Properties and Microstructure of Fire-Damaged Engineered Cementitious Composites. ACI Materials Journal, 107(3), 297-304.

Sarker, P. K., \& McBeath, S. (2015). Fire endurance of steel reinforced fly ash geopolymer concrete elements. Construction and Building Materials, 90, 91-98. https://doi.org/10.1016/j.conbuildmat.2015.04.054

Shaikh, F. U. A., \& Vimonsatit, V. (2015). Compressive strength of fly-ash-based geopolymer concrete at elevated temperatures. Fire and materials, 39(2), 174-188.

Si, R., Guo, S., Dai, Q., \& Wang, J. (2020). Atomic-structure, microstructure and mechanical properties of glass powder modified metakaolin-based geopolymer. Construction and Building Materials, 254, 119303. https://doi.org/10.1016/j.conbuildmat.2020.119303

Sim, J., Park, C., \& Moon, D. Y. (2005). Characteristics of basalt fiber as a strengthening material for concrete structures. Composites Part B: Engineering, 36(6-7), 504-512. https://doi.org/10.1016/j.compositesb.2005.02.002 
Tanyildizi, H., \& Yonar, Y. (2016). Mechanical properties of geopolymer concrete containing polyvinyl alcohol fiber exposed to high temperature. Construction and Building Materials, 126, 381-387. https://doi.org/10.1016/j.conbuildmat.2016.09.001

Topçu, I. B., \& Karakurt, C. (2008). Properties of reinforced concrete steel rebars exposed to high temperatures. Advances in Materials Science and Engineering, 2008, 1-4. https://doi.org/10.1155/2008/814137

Türker, H. T., Balçikanli, M., Durmuş, I. H., Özbay, E., \& Erdemir, M. (2016). Microstructural alteration of alkali activated slag mortars depend on exposed high temperature level. Construction and Building Materials, 104, 169-180. https://doi.org/10.1016/j.conbuildmat.2015.12.070

Uysal, M., Al-mashhadani, M. M., Aygörmez, Y., \& Canpolat, O. (2018). Effect of using colemanite waste and silica fume as partial replacement on the performance of metakaolin-based geopolymer mortars. Construction and Building Materials, 176 . https://doi.org/10.1016/j.conbuildmat.2018.05.034

Valencia Saavedra, W. G., \& Mejía de Gutiérrez, R. (2017). Performance of geopolymer concrete composed of fly ash after exposure to elevated temperatures. Construction and Building Materials, 154, 229-235. https://doi.org/10.1016/j.conbuildmat.2017.07.208

Xu, F., Deng, X., Peng, C., Zhu, J., \& Chen, J. (2017). Mix design and flexural toughness of PVA fiber reinforced fly ash-geopolymer composites. Construction and Building Materials, 150, 179-189. https://doi.org/10.1016/j.conbuildmat.2017.05.172

Yunsheng, Z., Wei, S., Zongiin, L., Xiangming, Z., Eddie, \& Chungkong, C. (2008). Impact properties of geopolymer based extrudates incorporated with fly ash and PVA short fiber. Construction and Building Materials, 22(3), 370-383. https://doi.org/10.1016/j.conbuildmat.2006.08.006

Zhang, H. Y., Kodur, V., Wu, B., Cao, L., \& Wang, F. (2016). Thermal behavior and mechanical properties of geopolymer mortar after exposure to elevated temperatures. Construction and Building Materials, 109, 17-24. https://doi.org/10.1016/j.conbuildmat.2016.01.043

Zhang, Y. J., Li, S., Wang, Y. C., \& Xu, D. L. (2012). Microstructural and strength evolutions of geopolymer composite reinforced by resin exposed to elevated temperature. Journal of Non-Crystalline Solids, 358(3), 620-624. https://doi.org/10.1016/j.jnoncrysol.2011.11.006 